\title{
Impractical magic
}

\section{A biography of alchemist John Dee sidesteps his impact on science, suggests Philip Ball.}

$\mathrm{T}$ he late-sixteenth-century mathematician and alchemist John Dee still exerts a powerful grip on the public imagination. Several novels have centred on him, including Peter Ackroyd's 1993 book The House of Doctor Dee. Damon Albarn of British band Blur debuted the pop opera Dr Dee in 2011. Now, in The Arch Conjuror of England, historian Glyn Parry gives us probably the most meticulous account so far of Dee and his career.

In some ways, all this attention seems disproportionate. Dee was less important in the philosophy of natural magic than the now relatively obscure Giambattista Della Porta and Cornelius Agrippa, and less significant as a transitional figure between magic and science than Della Porta and his contemporaries Bernardino Telesio and Tommaso Campanella, both anti-Aristotelian empiricists from Calabria in Italy. Dee's works, such as Monas Hieroglyphica, in which the unity of the cosmos was represented in a mystical symbol, were widely deemed impenetrable even in his own day.

Yet Dee was prominent during the Elizabethan age. He was probably the model for both William Shakespeare's Prospero in The Tempest and Ben Jonson's charlatan Subtle in the satire The Alchemist. Dee's glamour stems mostly, however, from the same source as that of Walter Raleigh and Francis Drake: they all fell within the orbit of Queen Elizabeth I herself. Benjamin Woolley's 2001 biography of Dee draws explicitly on this connection, calling him 'the queen's conjuror'. And he was precisely that, on and off.

There is no way to make sense of Dee without embedding him within the magical cult of Elizabeth, which also holds the keys to Edmund Spenser's epic poem The Faerie Queen and to the flights of fancy in A Midsummer Night's Dream. To the English, Elizabeth's reign heralded a mystical Protestant awakening. In Germany, that dream would die in the brutal Thirty Years' War; in England, it would spawn an empire. Dee coined the phrase 'the British Empire', but he looked less towards a colonial future than back to an imagined, magical realm of King Arthur.

As well as being versed in the 'occult arts' of alchemy and astrology, Dee was an able mathematician and an authority on navigation, cartography, cryptography and calendar reform. As Parry illustrates, there were no boundaries between these practical, intellectual and mystical disciplines in Elizabethan

culture. One of the book's strengths is its portrayal of how magic and the occult sciences were deeply woven into the fabric of that age.

Dee's relationship with the slippery Edward Kelley also feeds the popular fascination. Kelley claimed to be able to converse with angels through a crystal ball, and Dee's

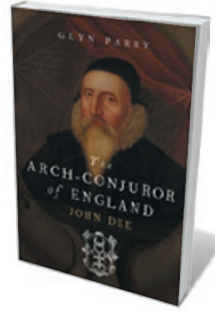

The Arch Conjuror of England: John

Dee

GLYN PARRY

Yale University Press: 2012. 384 pp. £25, $\$ 55$ and angelic commands never wavered, even when the increasingly deranged Kelley told him that the angels had commanded them to swap wives. During their ill-fated excursion to Poland and Prague in 1583, when they sought the patronage of Holy Roman Emperor Rudolf II, the servant-master relationship became inverted. Dee was reduced to a pathetic figure by the end of the trip.

He had left England after damaging his standing in Elizabeth's court, partly by throwing in his lot with a dubious visiting noble from Poland. He ruined his chances of receiving Rudolf's favour too, by passing on Kelley's angelic reprimand to the emperor for his errant ways.

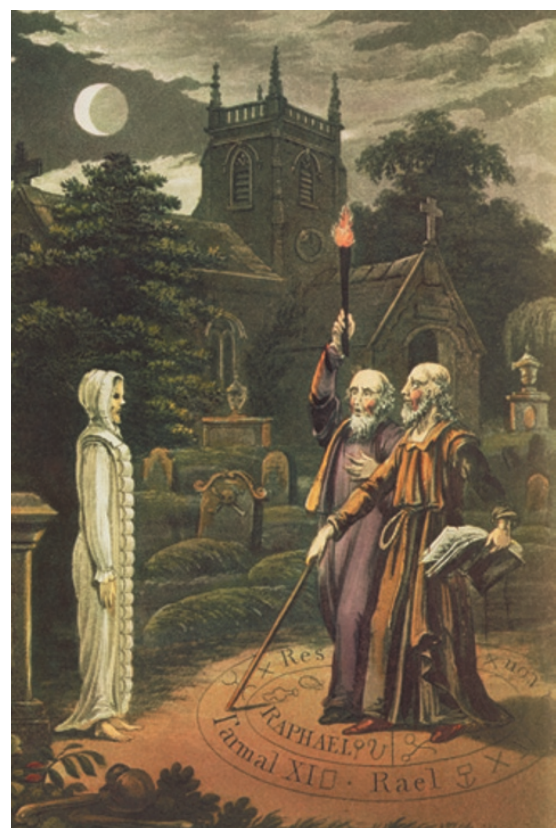

John Dee and Edward Kelley 'raising the dead'.
Dee was always making such misjudgements: he was hopeless at court politics. But he can't be held entirely to blame. As Parry highlights, negotiating the convoluted currents of the courts was fiendishly difficult, especially in England, where the memory of the bloody reign of Queen Mary I still hung in the air, along with a fear of papist plots. Unfortunately, Parry's presentation of these political intrigues often become as baffling as they must have been for Dee.

What I really missed was context: an indication of why Dee's magical enthusiasms were emblematic of the times and still felt in the 'scientific revolution' that followed. It is hard to locate Dee in history without hearing about contemporary figures who also sought to expand natural philosophy, such as Della Porta and Francis Bacon. Bacon, in particular, was another intellectual whose grand schemes and attempts to gain the queen's ear were hampered by court rivalries.

We need more than a cradle-to-grave story to understand Dee's significance. For example, although Parry explains the numerological and symbolic mysticism of his Monas Hieroglyphica, its preoccupation with divine and Adamic languages seems merely quirky if we are not told that this was a persistent concern, pursued later by the likes of the German Jesuit Athanasius Kircher (the most Dee-like figure of the early Enlightenment) and John Wilkins, a founder of the Royal Society.

Likewise, it would have been easier to evaluate Dee's mathematics if we knew that, until the mid-seventeenth century, maths was closely associated with both witchcraft and mechanical ingenuity, at which Dee excelled. Wilkins can provide orientation here too: he delighted in automata and devices, and describes them in his 1648 account Mathematical Magick, a direct descendant of Dee's famed 'Mathematical Preface' to a new translation of Euclid's Elements.

We would never know from The Arch Conjuror of England that Dee influenced the early modern scientific world through such transitional scholars as Robert Fludd, Elias Ashmole and Margaret Cavendish nor that his works were studied by Robert Boyle, and probably by Isaac Newton. Parry has assembled an important contribution to our understanding of how magic became science. It is a shame that he didn't see it as part of his task to make that connection.

Philip Ball is a writer based in London. 